\title{
Using brown seaweed as a biofertilizer in the crop management industry and assessing the nutrient upliftment of crops
}

\author{
Galabadage Indika Pavithrani Silva Makawita ${ }^{1,2 *}$, Indira Wickramasinghe², Isuru Wijesekara² \\ ${ }^{1}$ Faculty of Graduate Studies, University of Sri Jayewardenepura, Gangodawila, Nugegoda, Sri Lanka \\ ${ }^{2}$ Department of Food Science \& Technology, Faculty of Applied Sciences, University of Sri Jayewardenepura, Gangodawila, \\ Nugegoda, Sri Lanka
}

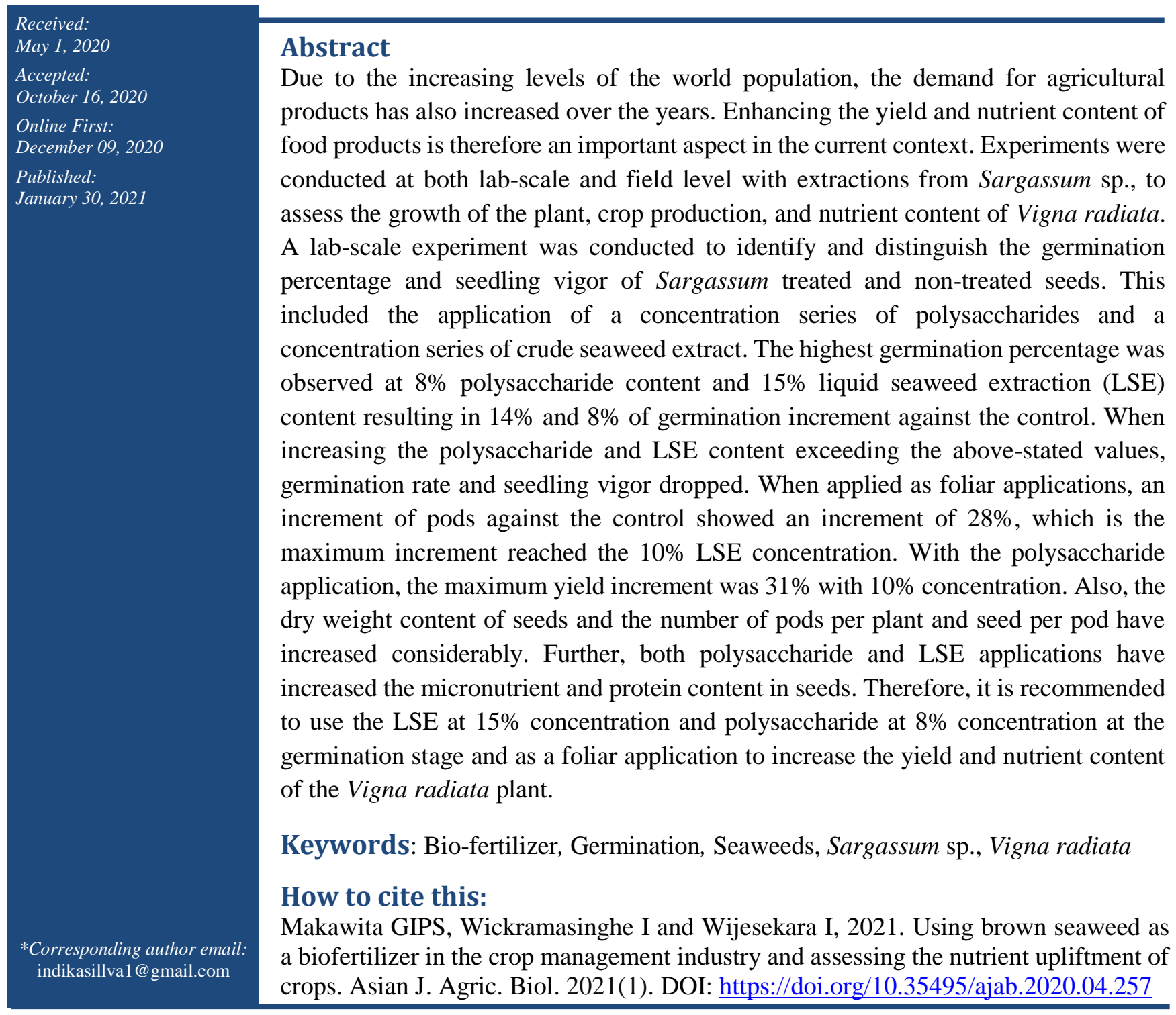

This is an Open Access article distributed under the terms of the Creative Commons Attribution 3.0 License. (https://creativecommons.org/licenses/by/3.0), which permits unrestricted use, distribution, and reproduction in any medium, provided the original work is properly cited. 


\section{Introduction}

Organic farming is considered an essential element in agriculture and usage of chemical fertilizers has become questionable in the recent past. Therefore, many agricultural practices tend to move towards organic farming coupled with biofertilizer applications, which are contributing to the deposition of residues and thereby improving the physical and chemical properties of the soil. Among the sources of supplemental fertilizers, algal biomass has been used in various continents to different extents. Seaweeds are used as nutrient supplements and biostimulants in agricultural and horticultural crop production and are known to enhance seed germination and seedling vigor. However, the growth-promoting activities of seaweeds are yet underexploited in South Asian agriculture though many studies have highlighted the impact that the seaweeds can make on vegetables, bulbous crops, flowers, legumes, and in vitro culture conditions. Seaweed extracts are known to increase the rate of germination, root and shoot growth development, improving the quality of the fruit and resistivity to pathogens (Rayorath et al., 2008; Mattner et al., 2013; Ali et al., 2015; Singh et al., 2015). Such growth-promoting activities of plants confirm the presence of plant growth regulators such as cytokinins, gibberellins, and auxins, as well as the presence of polyamines, polysaccharides, alginates, and fucoidans in brown seaweeds (Hong et al., 2007; González et al., 2013). The growth stimulation is evident by enhancing nitrogen assimilation and basal metabolism (González et al., 2013; Zhang and Ervin, 2008; Wang et al., 2016).

One such example of growth stimulation is the application of commercial seaweed extracts of Ascophyllum nodosum which has improved the growth of roots in Arabidopsis thaliana (Rayorath et al., 2008). Apart from regulating plant growth, there are many known benefits gained from seaweeds in plant cultivations as well, including; delaying fruit senescence, improvement of yield quantity and quality, and improving the ability to withstand adverse conditions. However, without much knowledge on the species and their activity, farmers in the coastal regions of Sri Lanka, harvest seaweeds and use them directly as compost and dry matter to improve the soil condition of the coastal regions of the country. Unlike the chemical fertilizers which are famous worldwide, seaweed extracts are biodegradable, non-toxic to both animals and humans, and non-polluting (Pramanick et al., 2013; Pal et al., 2015). Henceforth, the annual production of seaweed across the globe has risen to approximately 31.2 million tons from which a higher portion is used as nutrition supplements to improve plant growth (FAO, 2018).

Though a considerable amount of studies has been conducted to study the activity of seaweed species like Ascophyllum nodosum, Fucus serratus, Fucus vesiculosus, and Laminaria hyperborean, biology, composition, and the activity as growth stimulants of Sargassum varieties are not been reported widely. Therefore, it is considered as an under-utilized seaweed variety. Also, Sargassum sp. is rich in nutrients and minerals including the plant growth regulator; cytokinin (Crouch and Van, 1993). Henceforth, this study aims to evaluate the ability to utilize Sargassum sp. as a biofertilizer in improving the yield of Vigna radiata plants in organic farming agriculture.

\section{Material and Methods}

\section{Selection and description of the seaweed collection site}

Live specimens were collected from Hikkaduwa-Sri Lanka (Latitude: $6.1313^{\circ}$, Longitude: $80.1007^{\circ}$ ), a straight coastline eventually with a beach rock platform. Plants were grown in condensed populations and attached to the substrate by a disc; upright branches markedly compressed, smooth and straight. Leaves are 3-4 cm long, 5-7 mm wide, upwardly directed, and alternately placed on the axis in one plane, resulting in very flat plants; Air bladders are not observed. Specimens were in a sand substratum with having a sub-horizontal general coast inclination. Seagrass and seaweed vegetation was found as the biotopes and had an ecology of submerging at low tide, sand-covered bottom under low watermark (subtidal). In this site, the Sargassum sp. identified have formed intricate cushions in the prostrate growth direction. The in-situ colour of the species was brown.

\section{Seaweed sample collection from the site}

Specimens of Sargassum sp. were detached from its substrate, cleansed and epiphyte removal was done by washing with water at the collection site itself. These samples were then placed in iced containers to facilitate transportation. After reaching the destination, samples were sun-dried for 24 hours and oven-dried at $60^{\circ} \mathrm{C}$ for another 48 hours. Dried samples were grounded until a fine powder was 
obtained and sieved from $350 \mu \mathrm{m}$ mesh to obtain a fine powder. The acquired powder was placed in moisture $\&$ air proof containers and stored at $4^{\circ} \mathrm{C}$ until further use.

\section{Preparation of liquid seaweed extract (LSE)}

As per a previously established method, (Challen and Hemingway, 1966) LSE was prepared by mixing grounded seaweed powder with distilled water in a 1:1 ratio and was allowed to stand. Then the mixture was boiled, allowed to stand for some more time, and passed through a filter paper (Whatman Grade 1: 11 $\mu \mathrm{m})$ to remove solids. The resultant liquor was then centrifuged at $3000 \mathrm{rpm}$ for 3 minutes (Kubota 4000). Solids received from the initial filtration and centrifugation were pressed and the obtained liquor was mixed with the main liquor. The resultant liquor was then concentrated under reduced pressure to obtain a brown liquid. The LSE made is stored in the refrigerated conditions at $4^{0} \mathrm{C}$ until further use.

\section{Preparation of polysaccharide extract}

Exactly $100.00 \mathrm{~g}$ of the dried seaweed powder was mixed with 1 liter of distilled water and allowed to stand at $90^{\circ} \mathrm{C}$ for 1 hour (Makawita et al., 2019). After the designated time, the mix was cooled and centrifuged at $2000 \mathrm{rpm}$ for 10 minutes. The supernatant was collected, and three volumes of absolute ethanol were added. After standing for 5 minutes, again the mixture was centrifuged, and the supernatant was removed. The resultant extracted polysaccharide was dried in the oven at $40^{\circ} \mathrm{C}$ and a concentration series from $2 \%$ to $12 \%$ was prepared using distilled water (Table-2).

\section{Preparation of the substrate for seed growth}

The soil mixture was prepared by using clay, silt, and sand in 1:1:1 ratio in pots, topping up with a compost layer of $1 / 2$ inch (Zodape et al., 2010). To maintain substrate uniformity, a similar method was used to prepare the medium for the control sample.

\section{Initial preparation of Vigna radiata seeds}

Certified beans from Vigna radiata MI 6 variety were purchased from the Field crop research \& development institute of Mahailluppallama in Sri Lanka, where the seeds were sorted to have equal weight and size. Selected seeds were then imbibed in distilled water for 24 hours at room temperature $\left(31^{\circ} \mathrm{C}\right)$ and drained and washed twice with distilled water and kept in dark on a filter paper surface for another 24 hours (Elke et al., 1981). Cotyledons of the seeds were then dipped in $10 \mathrm{ml}$ of polysaccharide extracts and LSE concentrate series and kept for 24 hours (Table-1).

Table-1. Treatment of seeds with LSE

\begin{tabular}{|c|l|c|c|}
\hline Sample & Condition & Duration & $\begin{array}{c}\text { No. of seeds } \\
\text { treated }\end{array}$ \\
\hline A1 (Control) & $\begin{array}{l}\text { Seeds soaked in } \\
\text { distilled water }\end{array}$ & 24 hours & 200 \\
\hline A8 & $\begin{array}{l}\text { Seeds soaked in } \\
10 \% \text { LSE }\end{array}$ & 24 hours & 400 \\
\hline A9 & $\begin{array}{l}\text { Seeds soaked in } \\
15 \% \text { LSE }\end{array}$ & 24 hours & 400 \\
\hline A10 & $\begin{array}{l}\text { Seeds soaked in } \\
20 \% \text { LSE }\end{array}$ & 24 hours & 400 \\
\hline A11 & $\begin{array}{l}\text { Seeds soaked in } \\
30 \% \text { LSE }\end{array}$ & 24 hours & 400 \\
\hline
\end{tabular}

Table-2. Treatment of seeds with polysaccharide extraction (PE)

\begin{tabular}{|l|l|c|c|}
\hline \multicolumn{1}{|c|}{ Sample } & \multicolumn{1}{c|}{ Condition } & Duration & $\begin{array}{c}\text { No. of seeds } \\
\text { treated }\end{array}$ \\
\hline A1 (Control) & $\begin{array}{l}\text { Seeds soaked in } \\
\text { distilled water }\end{array}$ & 24 hours & 200 \\
\hline A2 & $\begin{array}{l}\text { Seeds soaked in } \\
2 \% \text { PE }\end{array}$ & 24 hours & 400 \\
\hline A3 & $\begin{array}{l}\text { Seeds soaked in } \\
4 \% \text { PE }\end{array}$ & 24 hours & 400 \\
\hline A4 & $\begin{array}{l}\text { Seeds soaked in } \\
6 \% \text { PE }\end{array}$ & 24 hours & 400 \\
\hline A5 & $\begin{array}{l}\text { Seeds soaked in } \\
8 \% \text { PE }\end{array}$ & 24 hours & 400 \\
\hline A6 & $\begin{array}{l}\text { Seeds soaked in } \\
10 \% \text { PE }\end{array}$ & 24 hours & 400 \\
\hline A7 & $\begin{array}{l}\text { Seeds soaked in } \\
12 \% \text { PE }\end{array}$ & 24 hours & 400 \\
\hline
\end{tabular}

The germination percentage of seeds was calculated using the below equation, against the control sample.

Germination percentage $=$

$\frac{\text { Number of seeds with sprouts after } 48 \text { hours }}{\text { Number of seeds used for treatments }} X 100$

\section{Sowing of seeds and foliar applications}

The treated seeds were sown in the prepared pots and environmental conditions were given at an equal capacity from A1 to A11 samples. After the growth of root and shoot, observations were made for the first set of plants by removing from the soil substrate. For the remaining plants, foliar application of the extract was given at the flowering stage (Table-3). 
Table-3. Treatments given for plants as foliar applications, at the flowering stage

\begin{tabular}{|c|c|c|c|}
\hline Sample & Condition & Frequency & $\begin{array}{c}\text { No. of } \\
\text { plants } \\
\text { treated }\end{array}$ \\
\hline $\begin{array}{c}\text { A6 } \\
(\text { Control }) \\
\end{array}$ & $\begin{array}{l}\text { Plants sprayed } \\
\text { with water }\end{array}$ & \multirow{10}{*}{$\begin{array}{l}\text { Twice per day } \\
\text { (Morning } 8 \mathrm{am} \text {, } \\
\text { Evening } 5 \mathrm{pm}- \\
5 \text { sprays each } \\
\text { plant) }\end{array}$} & 100 \\
\hline A12 & $\begin{array}{l}\text { Plants sprayed } \\
\text { with 5\% LSE }\end{array}$ & & 200 \\
\hline A13 & $\begin{array}{l}\text { Plants sprayed } \\
\text { with } 10 \% \text { LSE }\end{array}$ & & 200 \\
\hline A14 & $\begin{array}{l}\text { Plants sprayed } \\
\text { with } 15 \% \text { LSE }\end{array}$ & & 200 \\
\hline A 15 & $\begin{array}{l}\text { Seeds soaked in } \\
2 \% \mathrm{PE}\end{array}$ & & 200 \\
\hline A16 & $\begin{array}{l}\text { Seeds soaked in } \\
4 \% \mathrm{PE}\end{array}$ & & 200 \\
\hline A17 & $\begin{array}{l}\text { Seeds soaked in } \\
6 \% \mathrm{PE}\end{array}$ & & 200 \\
\hline A18 & $\begin{array}{l}\text { Seeds soaked in } \\
8 \% \mathrm{PE}\end{array}$ & & 200 \\
\hline A19 & $\begin{array}{l}\text { Seeds soaked in } \\
10 \% \mathrm{PE}\end{array}$ & & 200 \\
\hline A 20 & $\begin{array}{l}\text { Seeds soaked in } \\
12 \% \mathrm{PE}\end{array}$ & & 200 \\
\hline
\end{tabular}

After 90 days, grain yield was calculated for all samples, along with pods per plant and grains per pod.

\section{Analysis of micronutrient and protein content in seeds}

Seeds were harvested from pods and were analyzed for micronutrients through ICP-OES and for proteins through the Kjeldahl method.

In the ICP-OES method, sample preparation was done by thoroughly blending the seeds to obtain uniformity across all samples. Homogenized samples were weighed to the nearest $0.001 \mathrm{~g}$ into a clean microwave vessel liner. The extraction process was conducted by using microwave digestion. About $5 \mathrm{ml}$ of ultra-pure grade $\mathrm{HNO}_{3}$ acid was added to each vessel and was placed in the microwave oven. After the digestion is complete after 20 minutes at $180^{\circ} \mathrm{C}$, vessels were allowed to cool and were transferred to a fume-hood to attain equilibrium with the room temperature. At the evaporation stage, vessel liners were placed in evaporation carousels and were placed in the microwave oven. To reduce the final volume to $1 \mathrm{ml}$, samples were exposed to $100^{\circ} \mathrm{C}$ temperature for 8 minutes. Once the vessels were cooled down to the room temperature, the assembly was removed. For the vessels where the total volume was lower than $1 \mathrm{ml}$, $\mathrm{HNO}_{3}$ was added until reaching $1 \mathrm{ml}$ of volume. Then the residual digest was transferred by washing with deionized water while keeping the volume less than 35 $\mathrm{ml}$. Then, $50 \mu \mathrm{l}$ of $5000 \mathrm{ppm}$ internal standard solution was added to the extract while bringing the total volume up to $50 \mathrm{ml}$ with the addition of deionized water. Finally, samples and controls were placed in the analyzer to identify and calculate mineral levels.

In determining the protein content, 3 steps were involved in the process.

\section{Digestion}

Approximately weighed $0.05 \mathrm{~g}$ of the specimens of the powdered Vigna radiata seeds were separately placed in folded papers and then in the dried Kjeldahl digestion flasks along with 2 Kjeldhal catalyst tablets $\left(\mathrm{Na}_{2} \mathrm{~S}_{2} \mathrm{O}_{8} / \mathrm{CuSO} 4\right)$ and $2.5 \mathrm{ml}$ of analytical reagent grade (AR) concentrated sulfuric acid $\left(\mathrm{H}_{2} \mathrm{SO}_{4}, \mathrm{AR}\right.$ grade). The digestion flask was then attached to the block digestor (DK 20), and the sample was allowed to digest at $420^{\circ} \mathrm{C}$ for 3 hours approximately until a clear solution was obtained. Triplicates from the samples were prepared using a similar method. After completion of the digestion, $10 \mathrm{ml}$ of ammonia-free distilled water was added after cooling down. Blank digestion was also carried out for each sample, without adding the sample.

\section{Distillation}

After the digestion was complete, contents in the digestion tubes were transferred to the distillation tube of the apparatus while adding an excess volume of $32 \%$ Sodium Hydroxide ( $\mathrm{NaOH}, \mathrm{AR}$ grade) and distilled water. At the same instance, $5 \mathrm{ml}$ of $4 \%$ boric acid $\left(\mathrm{H}_{3} \mathrm{BO}_{3}\right.$, AR grade) was placed in the titration unit while adding the Kjeldahl indicator (Bromocresol Green and Methyl red in Methanol). Distillation was continued for 2 minutes and the liberated ammonia was trapped.

\section{Titration}

The resultant solution was titrated with $0.1 \mathrm{M}$ Hydrochloric acid ( $\mathrm{HCl}, \mathrm{AR}$ grade) until reaching the endpoint of colour transition from a green colour to purple. The same procedure was carried out for a blank sample as well.

The following equation was used to calculate the protein content of samples.

$$
\text { Nitrogen }(\%)=\frac{(\text { Sample titre }- \text { Blank titre }) X \text { Molarity HCl X } 14}{\text { Sample weight X } 1000} \times 100
$$


The protein content is equal to the Nitrogen content $X$ a pre-determined factor; 6.25. Results were then compared against the control sample.

\section{Statistical analysis}

Data collected through the above methodologies were statistically analyzed based on ANOVA at a 95\% significance level, by using MINITAB 18 statistical software.

\section{Results}

As per the treatments of table 01 and table 02 , from A1 to A11 samples, seed germination percentage is demonstrated in Figure-1.

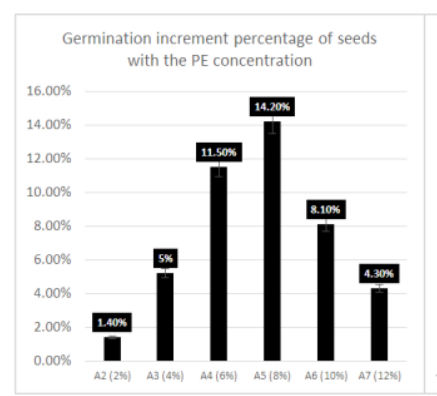

Figure-1. Increment of seed germination percentage against the control (A1), with PE and LSE, concentrates

Data stipulated in figure-1 depicts a significant difference at each PE and LSE concentration at $\mathrm{p}<0.05$ level.

Germination was calculated during the stipulated 48hour time period and as per the observations, the highest germination percentage was observed in the PE with $8 \%$ concentration, followed by the $15 \%$ concentration of LSE. At 30\% LSE concentration germination level has dropped below that of the control. After observing the germination percentage, observations were made at the growth lengths of root \& shoot.

The LSE treated samples have shown a comparative growth when comparing with the control. However, it is also observed that the concentration of the treatments has played a crucial role in seedling growth. Subjected to extreme concentrations, the percentage of germination was less due to the increased respiratory activities. But at the moderate concentration, respiratory activities are also considered to be moderate and the germination has considerably increased (Table-4). In both shoot and root, the highest increment of length is observed in the A9 sample, where the LSE is reached for $15 \%$. In this sample, growth increment against the control is $8.7 \%, 8.3 \%$ \& $12 \%$ respectively for shoot growth after 3,4 , and 5 days. In terms of the root growth, growth percentage is $9 \%, 7.1 \%$, and $8.7 \%$ for 3,4 , and 5 days respectively. Similarly, the A5 sample denotes the PE concentration of $8 \%$ and has shown significant growth over the control. It shows a growth increment of $13 \%$ within the first 3 days against the control and $12.5 \%$ and $12 \%$ for the following $4^{\text {th }}$ and $5^{\text {th }}$ days respectively. When considering the root, the growth was $7 \%, 8.9 \%$, and $8.7 \%$ for the consecutive days respectively. The highest values of root and shoot growth increment are significantly higher than the control and reduce with the further increment of the concentration.

For the foliar application given at the flowering stage, samples showed an obvious improvement of yield, against the control sample (Table-5).

Pods were collected at maturity from each plant and have shown an increment until the 10\% LSE and PE concentration. The highest incremental number of pods was observed at $10 \%$ at both applications being $28 \%$ and $31 \%$ respectively. When the concentration was increased from this level, the yield has dropped significantly. Similarly, the number of seeds per pod has reached the maximum at the $10 \%$ level with $4.7 \%$ and $5.6 \%$ respectively for LSE and PE. Seeds were weighed after drying in the oven at $70^{\circ} \mathrm{C}$, to obtain a constant weight and the seed weight has reached the maximum with an increment of $6.8 \%$ (LSE) and 7.6\% (PE). However, seed weight increment has no significant difference against each treatment. Considering all the contributors, it is evident that the increment of the yield is mainly due to the increment of the seed yield and the number of pods per plant.

However, pod yield and the seed yield per pod along with the weight of the seed have increased with the application of LSE and PE and have reached its maximum at the $10 \%$ application of LSE and PE both.

Mineral and the protein content results have shown a significant difference with the application of the seaweed extract (Table-6). However, with the increment of the LSE and PE concentration, these significant differences were not observed. The highest mineral and protein content is observed in the $10 \%$ concentrated application of LSE and PE. Similar to the yield of pods and seeds when increasing the concentration of both PE and LSE, mineral and protein content decrease as well. 
Galabadage Indika Pavithrani Silva Makawita et al.

Table-4. Germination (root \& shoot lengths) of samples from Al to All

\begin{tabular}{|c|c|c|c|c|c|c|c|c|c|c|c|c|}
\hline \multirow{3}{*}{ Sample } & \multicolumn{6}{|c|}{ Shoot Length (cm) } & \multicolumn{6}{|c|}{ Root Length (cm) } \\
\hline & \multicolumn{2}{|c|}{3 Days } & \multicolumn{2}{|c|}{4 Days } & \multicolumn{2}{|c|}{5 Days } & \multirow{2}{*}{\begin{tabular}{|l}
3 Days \\
Length
\end{tabular}} & \multirow[b]{2}{*}{$95 \% \mathrm{CI}$} & \multirow{2}{*}{\begin{tabular}{|l}
4 Days \\
Length
\end{tabular}} & \multirow[b]{2}{*}{$95 \% \mathrm{CI}$} & \multirow{2}{*}{\begin{tabular}{|l}
5 Days \\
Length
\end{tabular}} & \multirow[b]{2}{*}{$95 \% \mathrm{CI}$} \\
\hline & Length & $95 \% \mathrm{CI}$ & Length & $95 \% \mathrm{CI}$ & Length & $95 \% \mathrm{CI}$ & & & & & & \\
\hline A1 & $\begin{array}{l}2.3 \pm \\
0.1^{\text {cd }}\end{array}$ & $2.2132,2.3228$ & $\begin{array}{l}2.4 \pm \\
0.0^{\mathrm{ab}}\end{array}$ & $2.3242,2.4118$ & $\begin{array}{l}2.5 \pm \\
0.1^{\mathrm{cd}}\end{array}$ & $2.4148,2.5052$ & $\begin{array}{c}5.6 \pm \\
0.1^{\mathrm{e}}\end{array}$ & $5.5123,5.5917$ & $\begin{array}{c}5.6 \pm \\
0.0^{\mathrm{e}}\end{array}$ & $5.5113,5.5927$ & $\begin{array}{c}5.7 \pm \\
0.0^{\mathrm{d}}\end{array}$ & $5.6124,5.6996$ \\
\hline $\mathrm{A} 2$ & $\begin{array}{l}2.3 \pm \\
0.1^{\mathrm{cd}}\end{array}$ & $2.2132,2.3228$ & $\begin{array}{c}2.5 \pm \\
0.0^{\mathrm{a}}\end{array}$ & $2.4082,2.4958$ & $\begin{array}{l}2.5 \pm \\
0.1^{\mathrm{cd}}\end{array}$ & $2.4068,2.4972$ & $\begin{array}{c}5.8 \pm \\
0.0^{\mathrm{c}}\end{array}$ & $5.7763,5.8557$ & $\begin{array}{l}5.8 \pm \\
0.1^{\mathrm{bc}}\end{array}$ & $5.7753,5.8567$ & $\begin{array}{c}5.9 \pm \\
0.1^{\mathrm{c}}\end{array}$ & $5.8084,5.8956$ \\
\hline $\mathrm{A} 3$ & $\begin{array}{l}2.3 \pm \\
0.2^{\text {cd }}\end{array}$ & $2.2252,2.3348$ & $\begin{array}{c}2.5 \pm \\
0.1^{\mathrm{a}}\end{array}$ & $2.4082,2.4958$ & $\begin{array}{l}2.6 \pm \\
0.1^{\mathrm{bc}}\end{array}$ & $2.5108,2.6012$ & $\begin{array}{l}5.9 \pm \\
0.0^{\mathrm{bc}}\end{array}$ & $5.8643,5.9437$ & $\begin{array}{c}5.9 \pm \\
0.1^{\mathrm{b}}\end{array}$ & $5.8633,5.9447$ & $\begin{array}{c}6.0 \pm \\
0.0^{\mathrm{b}}\end{array}$ & $5.9124,5.9996$ \\
\hline A4 & $\begin{array}{l}2.4 \pm \\
0.2^{\mathrm{bc}}\end{array}$ & $2.3292,2.4388$ & $\begin{array}{c}2.6 \pm \\
0.2^{\mathrm{b}}\end{array}$ & $2.5082,2.5958$ & $\begin{array}{l}2.7 \pm \\
0.1^{\mathrm{ab}} \\
\end{array}$ & $2.6108,2.7012$ & $\begin{array}{c}6.0 \pm \\
0.2^{\mathrm{a}} \\
\end{array}$ & $5.9803,6.0597$ & $\begin{array}{c}6.0 \pm \\
0.0^{\mathrm{a}} \\
\end{array}$ & $5.9793,6.0607$ & $\begin{array}{l}6.1 \pm \\
0.0^{\mathrm{ab}}\end{array}$ & $6.0124,6.0996$ \\
\hline A5 & $\begin{array}{c}2.6 \pm \\
0.1^{\mathrm{a}}\end{array}$ & $2.5092,2.6188$ & $\begin{array}{c}2.7 \pm \\
0.1^{\mathrm{a}}\end{array}$ & $2.6122,2.6998$ & $\begin{array}{c}2.8 \pm \\
0.1^{\mathrm{a}}\end{array}$ & $2.7068,2.7972$ & $\begin{array}{c}6.0 \pm \\
0.1^{\mathrm{a}}\end{array}$ & $5.9843,6.0637$ & $\begin{array}{c}6.1 \pm \\
0.0^{\mathrm{a}}\end{array}$ & $6.0273,6.1087$ & $\begin{array}{c}6.2 \pm \\
0.1^{\mathrm{a}}\end{array}$ & $6.1084,6.1956$ \\
\hline A6 & $\begin{array}{c}2.1 \pm \\
0.1^{\mathrm{e}}\end{array}$ & $2.0172,2.1268$ & $\begin{array}{l}2.1 \pm \\
0.0^{\mathrm{d}}\end{array}$ & $2.0282,2.1158$ & $\begin{array}{c}2.2 \pm \\
0.2^{\mathrm{e}}\end{array}$ & $2.1068,2.1972$ & $\begin{array}{c}5.9 \pm \\
0.1^{\mathrm{b}}\end{array}$ & $5.8883,5.9677$ & $\begin{array}{l}5.8 \pm \\
0.1^{\mathrm{bc}}\end{array}$ & $5.8033,5.8847$ & $\begin{array}{c}5.8 \pm \\
0.1^{\mathrm{c}}\end{array}$ & $5.8004,5.8876$ \\
\hline A7 & $\begin{array}{c}2.0 \pm \\
0.1^{\mathrm{e}}\end{array}$ & $1.9372,2.0468$ & $\begin{array}{c}2.0 \pm \\
0.1^{\mathrm{d}} \\
\end{array}$ & $1.9482,2.0358$ & $\begin{array}{c}2.0 \pm \\
0.2^{\mathrm{f}}\end{array}$ & $1.9468,2.0372$ & $\begin{array}{c}5.7 \pm \\
0.0^{\mathrm{d}}\end{array}$ & $5.6803,5.7597$ & $\begin{array}{c}5.8 \pm \\
0.0^{\mathrm{c}}\end{array}$ & $5.7113,5.7927$ & $\begin{array}{l}5.8 \pm \\
0.0^{\text {cd }}\end{array}$ & $5.7084,5.7956$ \\
\hline A8 & $\begin{array}{c}2.3 \pm \\
0.1^{\mathrm{d}} \\
\end{array}$ & $2.1972,2.3068$ & $\begin{array}{c}2.5 \pm \\
0.2^{\mathrm{b}} \\
\end{array}$ & $2.4362,2.5238$ & $\begin{array}{c}2.5 \pm \\
0.1^{\mathrm{c}} \\
\end{array}$ & $2.4348,2.5252$ & $\begin{array}{c}5.7 \pm \\
0.0^{\mathrm{d}} \\
\end{array}$ & $5.6683,5.7477$ & $\begin{array}{l}5.6 \pm \\
0.1^{\mathrm{de}}\end{array}$ & $5.6033,5.6847$ & $\begin{array}{c}5.8 \pm \\
0.0^{c} \\
\end{array}$ & $5.7164,5.8036$ \\
\hline A9 & $\begin{array}{l}2.5 \pm \\
0.1^{\mathrm{ab}}\end{array}$ & $2.4532,2.5628$ & $\begin{array}{c}2.6 \pm \\
0.0^{\mathrm{b}}\end{array}$ & $2.5082,2.5958$ & $\begin{array}{c}2.8 \pm \\
0.1^{\mathrm{a}}\end{array}$ & $2.7068,2.7972$ & $\begin{array}{c}6.1 \pm \\
0.2^{\mathrm{a}}\end{array}$ & $6.0563,6.1357$ & $\begin{array}{c}6.0 \pm \\
0.1^{\mathrm{a}}\end{array}$ & $6.0073,6.0887$ & $\begin{array}{c}6.2 \pm \\
0.1^{\mathrm{a}} \\
\end{array}$ & $6.1124,6.1996$ \\
\hline A10 & $\begin{array}{l}2.3 \pm \\
0.0^{\text {cd }}\end{array}$ & $2.2052,2.3148$ & $\underset{\mathrm{ab}}{2.4 \pm 0.1}$ & $2.3202,2.4078$ & $\begin{array}{l}2.5 \pm \\
0.1^{\text {cd }}\end{array}$ & $2.4068,2.4972$ & $\begin{array}{c}5.5 \pm \\
0.0^{\mathrm{e}}\end{array}$ & $5.4723,5.5517$ & $\begin{array}{l}5.6 \pm \\
0.2^{\text {de }}\end{array}$ & $5.5313,5.6127$ & $\begin{array}{c}5.8 \pm \\
0.0^{\mathrm{c}}\end{array}$ & $5.7204,5.8076$ \\
\hline A11 & $\begin{array}{c}2.1 \pm \\
0.1^{\mathrm{e}}\end{array}$ & $2.0132,2.1228$ & $\begin{array}{c}2.1 \pm \\
0.1^{\mathrm{d}}\end{array}$ & $2.0242,2.1118$ & $\begin{array}{c}2.4 \pm \\
0.1^{\mathrm{d}}\end{array}$ & $2.3108,2.4012$ & $\begin{array}{c}5.5 \pm \\
0.1^{\mathrm{e}}\end{array}$ & $5.5083,5.5877$ & $\begin{array}{l}5.7 \pm \\
0.0^{\mathrm{d}}\end{array}$ & $5.6113,5.6927$ & $\begin{array}{c}5.8 \pm \\
0.1^{\mathrm{c}}\end{array}$ & $5.7204,5.8076$ \\
\hline
\end{tabular}

Table-5. Yield of pods and seeds after foliar application of LSE \& PE

\begin{tabular}{|c|c|c|c|c|c|c|c|c|}
\hline Sample & \begin{tabular}{|c|} 
No. of pods \\
per plant
\end{tabular} & $95 \% \mathrm{CI}$ & \begin{tabular}{|c|}
$\begin{array}{c}\text { No. of seeds } \\
\text { per pod }\end{array}$ \\
\end{tabular} & $95 \% \mathrm{CI}$ & \begin{tabular}{|l|}
$\begin{array}{l}\text { Seed yield } \\
\text { per plant }(\mathrm{g})\end{array}$ \\
\end{tabular} & $95 \% \mathrm{CI}$ & $\begin{array}{c}\begin{array}{c}\text { Weight of } 100 \\
\text { seeds }(\mathrm{g})\end{array} \\
\end{array}$ & $95 \% \mathrm{CI}$ \\
\hline A6 & $18.92 \pm 0.7^{\mathrm{d}}$ & $18.542,19.308$ & $8.51 \pm 0.4^{\mathrm{bc}}$ & $8.327,8.709$ & $12.51 \pm 0.4^{\mathrm{e}}$ & $12.3247,12.6973$ & $3.98 \pm 0.2^{\mathrm{bcd}}$ & $3.8472,4.0928$ \\
\hline A12 & $21.53 \pm 0.4^{c}$ & $21.134,21.900$ & $8.64 \pm 0.1^{\mathrm{ab}}$ & $8.437,8.819$ & $15.94 \pm 0.1^{\mathrm{b}}$ & $15.7597,16.1323$ & $4.12 \pm 0.4^{\mathrm{abc}}$ & $4.0012,4.2468$ \\
\hline A13 & $24.21 \pm 0.3^{\mathrm{a}}$ & $23.840,24.606$ & $8.91 \pm 0.1^{\mathrm{ab}}$ & $8.7234,9.1046$ & $16.13 \pm 0.2^{\mathrm{b}}$ & $15.958,16.330$ & $4.25 \pm 0.4^{\mathrm{a}}$ & $4.1422,4.3878$ \\
\hline A14 & $19.53 \pm 0.1^{\mathrm{d}}$ & $19.125,19.891$ & $8.73 \pm 0.2^{\mathrm{ab}}$ & $8.543,8.925$ & $15.87 \pm 0.1^{\mathrm{b}}$ & $15.6807,16.0533$ & $4.08 \pm 0.2^{\mathrm{abc}}$ & $3.9582,4.2038$ \\
\hline A15 & $17.54 \pm 0.1^{\mathrm{e}}$ & $17.146,17.912$ & $8.60 \pm 0.1^{\mathrm{ab}}$ & $8.4184,8.7996$ & $13.45 \pm 0.2^{\mathrm{d}}$ & $13.273,13.645$ & $3.65 \pm 0.3^{\mathrm{e}}$ & $3.5232,3.7688$ \\
\hline A16 & $19.17 \pm 0.5^{\mathrm{d}}$ & $18.781,19.547$ & $8.65 \pm 0.1^{\mathrm{ab}}$ & $8.4494,8.8306$ & $14.67 \pm 0.4^{\mathrm{c}}$ & $14.4777,14.8503$ & $3.74 \pm 0.2^{\mathrm{de}}$ & $3.6192,3.8648$ \\
\hline A17 & $20.96 \pm 0.5^{c}$ & $20.570,21.336$ & $8.70 \pm 0.2^{\mathrm{ab}}$ & $8.517,8.899$ & $16.11 \pm 0.7^{\mathrm{b}}$ & $15.9117,16.2843$ & $3.95 \pm 0.1^{\mathrm{cd}}$ & $3.8272,4.0728$ \\
\hline A18 & $22.43 \pm 0.4^{b}$ & $22.036,22.802$ & $8.71 \pm 0.2^{\mathrm{ab}}$ & $8.5224,8.9036$ & $16.67 \pm 0.5^{\mathrm{a}}$ & $16.4707,16.8433$ & $4.10 \pm 0.0^{\mathrm{abc}}$ & $3.9802,4.2258$ \\
\hline A19 & $24.76 \pm 0.8^{\mathrm{a}}$ & $24.370,25.136$ & $8.99 \pm 0.1^{\mathrm{a}}$ & $8.7964,9.1776$ & $16.84 \pm 0.6^{\mathrm{a}}$ & $16.6427,17.0153$ & $4.31 \pm 0.2^{\mathrm{a}}$ & $4.1892,4.4348$ \\
\hline A20 & $19.34 \pm 0.4^{\mathrm{d}}$ & $18.971,19.737$ & $8.10 \pm 0.2^{c}$ & $7.8944,8.2756$ & $16.10 \pm 0.5^{b}$ & $15.9197,16.2923$ & $4.25 \pm 0.3^{\mathrm{ab}}$ & $4.1252,4.3708$ \\
\hline
\end{tabular}


Galabadage Indika Pavithrani Silva Makawita et al.

Table-6. Mineral and protein content of the seeds of LSE and PE treated samples

\begin{tabular}{|c|c|c|c|c|c|c|c|c|c|c|c|c|}
\hline \multicolumn{13}{|c|}{ Mineral and protein content in mg per 100g of Vigna radiata seed flour } \\
\hline Sample & $\mathbf{C a}$ & $95 \% \mathrm{CI}$ & $\mathbf{F e}$ & $95 \% \mathrm{CI}$ & Mg & $95 \% \mathrm{CI}$ & $\mathbf{K}$ & $95 \% \mathrm{CI}$ & $\mathrm{Na}$ & $95 \% \mathrm{CI}$ & Protein & $95 \% \mathrm{CI}$ \\
\hline A6 & $\begin{array}{c}78.1 \pm \\
0.0^{\mathrm{d}}\end{array}$ & $77.376,78.764$ & $\begin{array}{c}8.1 \pm \\
0.0^{\mathrm{e}}\end{array}$ & $7.9817,8.2183$ & $\begin{array}{c}50.1 \pm \\
0.0^{\mathrm{i}}\end{array}$ & $49.477,50.643$ & $\begin{array}{c}335.4 \pm \\
0.0^{\mathrm{e}}\end{array}$ & $334.562,336.338$ & $\begin{array}{c}10.3 \pm \\
0.0^{\mathrm{f}}\end{array}$ & $10.2548,10.4252$ & $\begin{array}{c}21.0 \pm \\
0.1^{\mathrm{e}}\end{array}$ & $20.525,21.455$ \\
\hline A12 & $\begin{array}{c}79.3 \pm \\
0.1^{\text {bcd }}\end{array}$ & $78.566,79.954$ & $\begin{array}{l}8.4 \pm \\
0.0^{\mathrm{d}}\end{array}$ & $8.3217,8.5583$ & $\begin{array}{c}50.8 \pm \\
0.0^{\text {efg }}\end{array}$ & $50.247,51.413$ & $\begin{array}{c}338.7 \pm \\
0.0^{\text {cd }}\end{array}$ & $337.832,339.608$ & $\begin{array}{c}11.6 \pm \\
0.0^{\mathrm{d}}\end{array}$ & $11.5048,11.6752$ & $\begin{array}{c}20.7 \pm \\
0.2^{\mathrm{e}}\end{array}$ & $20.245,21.175$ \\
\hline A13 & $\begin{array}{c}80.2 \pm \\
0.0^{\mathrm{b}}\end{array}$ & $79.486,80.874$ & $\begin{array}{l}9.0 \pm \\
0.1^{\mathrm{bc}}\end{array}$ & $8.8307,9.0673$ & $\begin{array}{c}53.8 \pm \\
0.1^{\mathrm{bc}}\end{array}$ & $53.187,54.353$ & $\begin{array}{c}341.2 \pm \\
0.0^{\mathrm{b}}\end{array}$ & $340.862,342.638$ & $\begin{array}{c}12.4 \pm \\
0.1^{\mathrm{a}}\end{array}$ & $12.3448,12.5152$ & $\begin{array}{c}24.2 \pm \\
0.1^{\mathrm{b}}\end{array}$ & $23.765,24.695$ \\
\hline A14 & $\begin{array}{c}78.5 \pm \\
0.0^{\text {cd }}\end{array}$ & $77.826,79.214$ & $\begin{array}{l}8.8 \pm \\
0.1^{\mathrm{bc}}\end{array}$ & $8.6937,8.9303$ & $\begin{array}{c}51.6 \pm \\
0.1^{\mathrm{ef}}\end{array}$ & $50.997,52.163$ & $\begin{array}{c}338.7 \pm \\
0.0^{\mathrm{cd}}\end{array}$ & $337.852,339.628$ & $\begin{array}{c}11.8 \pm \\
0.1^{\mathrm{c}}\end{array}$ & 11.734811 .9052 & $\begin{array}{c}21.8 \pm \\
0.3^{\mathrm{de}}\end{array}$ & $21.295,22.225$ \\
\hline A15 & $\begin{array}{r}79.2 \pm \\
0.1^{\text {bcd }} \\
\end{array}$ & $78.486,79.874$ & $\begin{array}{l}8.8 \pm \\
0.0^{\mathrm{bc}}\end{array}$ & $8.7117,8.9483$ & $\begin{array}{c}50.4 \pm \\
0.0^{\mathrm{fg}} \\
\end{array}$ & $49.827,50.993$ & $\begin{array}{c}337.2 \pm \\
0.1^{\text {de }}\end{array}$ & $336.362,338.138$ & $\begin{array}{c}10.4 \pm \\
0.1^{\mathrm{f}} \\
\end{array}$ & $10.3148,10.4852$ & $\begin{array}{c}21.0 \pm \\
0.2^{\mathrm{e}}\end{array}$ & $20.575,21.505$ \\
\hline A16 & $\begin{array}{c}80.1 \pm \\
0.1^{\mathrm{bc}} \\
\end{array}$ & $79.426,80.814$ & $\begin{array}{c}8.7 \pm \\
0.0^{c} \\
\end{array}$ & $8.6117,8.8483$ & $\begin{array}{c}50.2 \pm \\
0.0^{\mathrm{g}} \\
\end{array}$ & $49.577,50.743$ & $\begin{array}{c}340.8 \pm \\
0.1^{\mathrm{bc}}\end{array}$ & $339.872,341.648$ & $\begin{array}{c}11.0 \pm \\
0.0^{\mathrm{e}} \\
\end{array}$ & $10.9448,11.1152$ & $\begin{array}{c}22.3 \pm \\
0.1^{\mathrm{d}}\end{array}$ & $21.795,22.725$ \\
\hline A17 & $\begin{array}{c}80.1 \pm \\
0.0^{\mathrm{b}}\end{array}$ & $79.436,80.824$ & $\begin{array}{l}8.9 \pm \\
0.0^{\mathrm{bc}}\end{array}$ & $8.7917,9.0283$ & $\begin{array}{c}52.1 \pm \\
0.1^{\mathrm{de}}\end{array}$ & $51.517,52.683$ & $\begin{array}{c}340.7 \pm \\
0.1^{\mathrm{bc}}\end{array}$ & $339.782,341.558$ & $\begin{array}{c}11.2 \pm \\
0.0^{\mathrm{e}}\end{array}$ & $11.1248,11.2952$ & $\begin{array}{c}22.5 \pm \\
0.2^{\text {cd }}\end{array}$ & $21.985,22.915$ \\
\hline A18 & $\begin{array}{c}82.4 \pm \\
0.0^{\mathrm{a}}\end{array}$ & $81.666,83.054$ & $\begin{array}{l}9.1 \pm \\
0.1^{\mathrm{b}}\end{array}$ & $8.9417,9.1783$ & $\begin{array}{c}54.9 \pm \\
0.1^{\mathrm{ab}}\end{array}$ & $54.357,55.523$ & $\begin{array}{c}342.5 \pm \\
0.0^{\mathrm{b}}\end{array}$ & $341.662,343.438$ & $\begin{array}{c}12.1 \pm \\
0.0^{\mathrm{b}}\end{array}$ & $11.9748,12.1452$ & $\begin{array}{c}23.4 \pm \\
0.2^{\mathrm{bc}}\end{array}$ & $22.935,23.865$ \\
\hline A19 & $\begin{array}{c}83.7 \pm \\
0.1^{\mathrm{a}}\end{array}$ & $83.006,84.394$ & $\begin{array}{c}9.4 \pm \\
0.1^{\mathrm{a}}\end{array}$ & $9.2517,9.4883$ & $\begin{array}{c}55.6 \pm \\
0.0^{\mathrm{a}}\end{array}$ & $54.977,56.143$ & $\begin{array}{c}345.8 \pm \\
0.0^{\mathrm{a}}\end{array}$ & $344.912,346.688$ & $\begin{array}{c}2.4^{\mathrm{a}} \\
0.1^{\mathrm{a}}\end{array}$ & $12.3248,12.4952$ & $\begin{array}{c}25.4 \pm \\
0.3^{\mathrm{a}}\end{array}$ & $24.955,25.885$ \\
\hline $\mathrm{A} 20$ & $\begin{array}{c}80.0 \pm \\
0.0^{\mathrm{bc}}\end{array}$ & $79.342,80.730$ & $\begin{array}{c}9.1 \pm \\
0.1^{\mathrm{b}}\end{array}$ & $8.9317,9.1683$ & $\begin{array}{c}53.0 \pm \\
0.0^{\text {cd }}\end{array}$ & $52.437,53.603$ & $\begin{array}{c}338.6 \pm \\
0.0^{\mathrm{d}}\end{array}$ & $337.672,339.448$ & $\begin{array}{c}11.8 \pm \\
0.1^{\mathrm{c}}\end{array}$ & $11.7448,11.9152$ & $\begin{array}{c}24.1 \pm \\
0.1^{\mathrm{b}}\end{array}$ & $23.675,24.605$ \\
\hline
\end{tabular}

\section{Discussion}

Polysaccharide and crude seaweed extractions of Sargassum sp. are used in this study to identify their impact on the rate of germination, growth, pod and seed yield, and nutrient content analysis of Vigna Radiata seeds. Increasing the yield in crops, with the application of seaweed extracts are reported for Capsicum annum (Arthur et al., 2003), Zea mays (Rajkumar and Subramanian, 1999) \& Brassica napus (Ferreira and Lourens, 2002). In a parallel study, the seaweed Kappaphycus has increased the yield of all concentrations of nutrient supply by increasing the weight of the bean (Beckett et al., 1994). The increment in the germination, growth, and yield in low concentration of seaweed extracts might occur due to the presence of gibberellin, cytokinin like growth regulators, phenylacetic acid (Sivasankari et al., 2006), and micronutrients (Layek et al., 2014).

Soaking the seeds with lower concentrations of the extracts showed an improvement of growth and yield factors against the control. The highest germination percentage was observed in PE with $8 \%$ concentration and in LSE with a $15 \%$ concentration. This signifies that a PE with lesser concentration can achieve a stipulated growth when comparing with LSE. Therefore, quantity-wise, it will be more beneficial to use PE than LSE, in crop production. However, at 20\% concentration of LSE and $10 \%$ concentration of PE, the germination rate has been initiated to reduce, compared with the control. This signifies that there is an optimum concentration of LSE and PE, which could be used in crop production. It is evident that unless used at the optimum concentration, higher dosages of both PE and LSE will reduce the rate of germination due to the excessive stress resulting reduction of growth rate (Sivasankari et al., 2006).

When considering the growth attributes including the root and shoot length, maximum growth was observed at $8 \%$ polysaccharide and $15 \%$ crude seaweed extract concentration. At LSE 15\% concentration, the root had an average growth of $8.3 \%$, while the shoot had an average growth of $9.6 \%$ against the control. At $8 \% \mathrm{PE}$, the shoot had a $12.5 \%$ growth while the root had $8.2 \%$ average growth against the control. This observation in obtaining the highest growth at comparatively a low concentration of PE, compared to LSE is due to the concentrated amount of growth regulators in PE against LSE, which might have advanced the photosynthesis thereby stimulating vegetative growth (Devi and Mani, 2015). This observation has also been made for gram (Pramanick et al., 2013) and wheat (Shah et al., 2013). Further to these studies, it is also highlighted that the presence of bioactive substances is likely to improve the intake of stomatal uptake efficiency (Mancuso et al., 2006; Rathore et al., 2009). Since both PE and LSE had concentrated levels of bioactive substances, it is likely to have impacted the plant growth positively. Also, the presence of growth regulators advances photosynthesis, thereby increasing the growth of crops. However, overdosing of the LSE and PE has impacted the growth rate 
similar to the germination rate, stressing the fact that excessive stress can demote the crop growth rate.

When considering the improvement of the seed and pod yield, $10 \%$ was the LSE and PE extraction concentration which gave the highest yield against the control. Yield has improved up to $31 \%$ from these applications, which is statistically significantly different from one another as well. Weights of the grains have also increased significantly and have reached the highest at $10 \%$ concentration at both of the application types. The result signifies that the yield of the Vigna radiata crop has increased significantly when applying LSE and PE. The number of pods per plant as well as the number of seeds per pod has increased significantly, thereby increasing the number of seeds per plant.

These observations could be related to the movement of the resultants of photosynthesis from the vegetative parts to the development parts of the plant; grains (Shah et al., 2013). The observation could be justified by another study done on the green gram (Pramanick et al., 2013) by the application of Kappaphycus alvarezii and Gracilaria edulis.

Protein content analysis of seeds has resulted in obtaining the highest yield from 10\% application of both LSE and PE. Also, mineral contents of $\mathrm{Ca}, \mathrm{Fe}$, $\mathrm{Mg}, \mathrm{K}, \mathrm{Na}$ has increased with the increasing levels of the application concentration and have reached the maximum at $10 \%$ concentration. This may be due to the ability of Sargassum to increase nutrient utilization from the soil while adding as an additional mineral source to the crop.

Similar results have been observed in Vitis vinifera and Cucumis sativus with the seaweed applications (Turan and Kose, 2004; Mancuso et al., 2006). The reason for the high mineral and nutrient content after seaweed application is highlighted as due to the ability of seaweeds to enhance the effectiveness of fertilizers by increasing nutrient utilization by soil (Frankenberger and Arshad, 1995; Sharma et al., 2014). When considering the protein content, the increment is around $20 \%$ for both LSE and PE and is significantly different from the control. The same result has been reported for Vigna catajung (Anantharaj and Venkatesalu, 2001) and the result is justified by the root proliferation and thereby an increment in $\mathrm{N}, \mathrm{P}$, and $\mathrm{S}$ uptake, which is needed for protein synthesis. It was also observed that the seaweed applications have increased micronutrient content in rice grains like $\mathrm{Cu}$ and $\mathrm{Zn}$ up to $10 \%$ concentrations and $\mathrm{Fe}$ and $\mathrm{Mn}$ up to $5 \%$ concentrations
(Layek et al., 2014).

\section{Conclusion}

With these analytical results, it is evident that the extractions of seaweeds could be used to improve the rate of seed germination, growth, and the yield of plants. Based on the result of this study, it is recommended to use the LSE at $15 \%$ concentration and polysaccharide extraction at $8 \%$ concentration at the germination stage and as a foliar application to increase the yield and nutrient content of the Vigna radiata plant. Also, Sargassum sp. applications improve the mineral and protein uptake of plants and thereby impacting the mineral and protein levels of the Vigna radiata seed crop.

Disclaimer: None.

Conflict of Interest: None.

Source of Funding: This research was funded by the University research grant from the University of Sri Jayewardenepura, Sri Lanka, under the grant number ASP/01/RE/SCI/2019/10.

\section{References}

Ali N, Farrell A, Ramsubhag A and Jayaraman J, 2015. The effect of Ascophyllum nodosum extract on the growth, yield and fruit quality of tomato grown under tropical conditions. J. Appl. Phycol. 10:15-20.

Anantharaj M and Venkatesalu V, 2001. Studies on the effect of seaweed extracts on Dolichos bixorus. Seaweed Res. Utiln. 24(1):129-137.

Arthur GD, Stirk WA and Van SJ, 2003. Effect of seaweed concentrates on the growth and yield of three varieties of Capsicum annum. S. Afr. J. Bot. 69:207-211.

Beckett RP, Mathegka ADM and Van SJ, 1994. Effect of seaweed concentrate on yield of nutrient stressed tepary bean (Phaseolus acutifolius). J. Appl. Phycol. 16:429-430.

Challen SB and Hemingway JC, 1966. Growth of higher plants in response of feeding with seaweed extracts, pp. 359-367. In Proceedings, $5^{\text {th }}$ International Seaweed Symposium, 25-28 August 1966, Halifax Publisher, Oxford.

Crouch IJ and Van SJ, 1993. Evidence for the presence of plant growth regulators in commercial seaweed products. J. Pl. Gro. Regul. 13:21-29. 
Devi NL and Mani S, 2015. Effect of seaweed saps Kappaphycus alvarezii and Gracilaria on growth, yield and quality of rice. Ind. J. Sci. Tech. 10:1927.

Elke L, Regina P and Karl AW, 1981. The Appearance of New Active Forms of Trypsin Inhibitor in Germinating Mung Bean (Vigna radiata) Seeds. Plant Physiol. 68:88-92.

FAO (Food and Agricultural Organization), 2018. The state of world fisheries and aquaculture. License: CC BY-NC-SA 3.0 IGO. FAO, Rome.

Ferreira MI and Lourens AF, 2002. The efficacy of liquid seaweed extract on the yield of Canola plants. S. Afr. J. Plant Soil. 19:159-161.

Frankenberger WT and Arshad M, 1995. Phytohormones in soils: microbial production and function. Marcel Dekker Inc., New York, USA.

González A, Castro J, Vera J, and Moenne A, 2013. Seaweed oligosaccharides stimulate plant growth by enhancing carbon and nitrogen assimilation, basal metabolism, and cell division. J. Plant Growth. Regul. 32:443-448.

Hong DD, Hien HM and Son PN, 2007. Seaweeds from Vietnam used for functional food, medicine and biofertilizer. J. Appl. Phycol. 19:817-826.

Layek J, Ramkrushna GI, Das A, Ghosh A, Krishnappa R, Panwar AS, Azad Thakur NS, Ngachan SV, Zodape ST, Buragohain J and Mawlong B, 2014. Seaweed sap as organic bio stimulant for rice and maize production. Res. Bull. ICAR Com. NEH. Reg. 82: 128.

Makawita GIPS, Wickramasinghe I and Wijesekara I, 2019. Crude alginate extraction from brown seaweed Sargassum spp. and formulation of beads as a stabilizer, in the ice cream industry, pp.13-20. In Proceedings, $5^{\text {th }}$ Annual research session of Institute of Food Science \& Technology SL, $3^{\text {rd }}$ August 2019, Food Techno, Colombo, SL.

Mancuso S, Azzarello E, Mugnai S and Briand X, 2006. Marine bioactive substances (IPA extract) improve foliar ion uptake and water tolerance in potted Vitis vinifera plants. J. Adv. Hort. Sci. 20:156-161.

Mattner SW, Wite D, Riches DA, Porter IJ and Arioli $\mathrm{T}, 2013$. The effect of kelp extract on seedling establishment of broccoli on contrasting soil types in southern Victoria, Australia. J. Biol. Agric. Hort. 29:258-270.

Pal A, Dwivedi SK, Maurya PK and Kanwar P, 2015. Effect of seaweed saps on growth, yield, nutrient uptake and economic improvement of maize (sweet corn). J. Appl. Nat. Sci. 7:970-975.

Pramanick B, Brahmachari K and Ghosh A, 2013. Effect of seaweed saps on growth and yield improvement of green gram. Afr. J. Agric. Res. 8:1180-1186.

Rajkumar IS and Subramanian SK, 1999. Effect of fresh extracts and seaweed liquid fertilizers on some cereals and millets. J. Seaweed Res. Utiln. 21:91-94.

Rathore SS, Chaudhary DR, Boricha GN, Ghosh A, Bhatt BP, Zodape ST and Patiola JS, 2009. Effect of seaweed extract on the growth, yield and nutrient uptake of soybean (Glycine max) under rainfed conditions. S. Afr. J. Bot. 75:351-355.

Rayorath P, Khan W, Palanisamy R, MacKinnon SL, Stefanova R, Hankins SD, Critchley AT and Prithiviraj B, 2008. Extracts of the brown seaweed Ascophyllum nodosum induce gibberellic acid (GA3)-independent amylase activity in barley. J. Plant Growth Regul. 27:370-379.

Shah MT, Zodape ST, Chaudhary DR, Eswaran K and Chikara J, 2013. Seaweed sap as an alternative liquid fertilizer for yield and quality improvement of wheat. J. Plant Nutr. 36:192-200.

Sharma HSS, Fleming C, Selby C, Rao JR and Martin T, 2014. Plant biostimulants: a review on the processing of macroalgae and use of extracts for crop management to reduce abiotic and biotic stresses. J. Appl. Phycol. 26:465-490.

Singh S, Singh MK, Pal SK, Trivedi K, Yesuraj D, Singh CS, Vijay Anand KG, Chandramohan M, Patidar R, Kubavat D, Zodape ST and Arup G, 2015. Sustainable enhancement in yield and quality of rainfed maize through Gracilaria edulis and Kappaphycus alvarezii seaweed sap. J. Appl. Phycol. 28:400-429.

Sivasankari S, Venkatesalu V, Anantharaj M and Chandrasekaran M, 2006. Effect of seaweed extracts on the growth and biochemical constituents of Vigna sinensis. J. Bio. Tech. 97:1745-1751.

Turan M and Kose C, 2004. Seaweed extracts improve copper uptake of grapevine. J. Acta. Agri. Scand. B-S Pl. 54:213-220.

Wang Y, Fu F, Li J, Wang G, Wu M, Zhan J, Chen X and Mao Z, 2016. Effects of seaweed fertilizer on the growth of Malus hupehensis seedlings, soil enzyme activities and fungal communities under replant condition. Eur. J. Soil Biol. 75:1-7. 
Galabadage Indika Pavithrani Silva Makawita et al.

Zhang $X$ and Ervin EH, 2008. Impact of seaweed extract-based cytokinins and zeatin riboside on creeping bent grass heat tolerance. J. Crop Sci. 48:364-370.

Zodape ST, Mukhopadhyay S, Eswaran K, Reddy MP and Chikara J, 2010. Enhanced yield and nutritional quality in green gram (Phaseolus radiata $L$.) treated with seaweeds (Kappaphycus alvarezii) extract. J. Sci. Ind. Res. 60:468-471.

\section{Contribution of Authors}

Makawita GIPS: Conceived idea, designed researched methodology, data collection and analysis and manuscript writing

Wickramasinghe I \& Wijesekara I: Helped in designing the experiment, data analysis, data interpretation and manuscript writing 